\title{
Optimization of the work of a nutritionist physician using tools of lean technologies in a simulated clinic
}

\author{
O. V. Lisovskii, A. V. Gostimskii, I. A. Lisitsa, \\ A. N.Zavyalova, I. V. Karpatsky \\ St. Petersburg State Pediatric Medical University, \\ 2, Litovskaya ul., St. Petersburg, 194100, Russian Federation
}

For citation: Lisovskii O. V., Gostimskii A. V., Lisitsa I. A., Zavyalova A. N., Karpatsky I. V. Optimization of the work of a nutritionist physician using tools of lean technologies in a simulated clinic. Vestnik of Saint Petersburg University. Medicine, 2020, vol. 15, issue 4, pp. 283-289.

https://doi.org/10.21638/spbu11.2020.406

The article presents the possibilities of implementing the priority project "New model of medical organization providing primary health care" aimed at increasing the accessibility and satisfaction of patients with the quality of medical care. An example of an outpatient dietary consultation shows the resources for detecting medical losses and ways of optimizing the activities of medical personnel using the tools of lean technologies. The article reflects the experience of the Training Centre for lean technologies in health care of the Saint Petersburg State pediatric medical university, created in 2018 with the aim of training medical workers of different specialties to use tools of economical production in conditions of simulated clinic. The conduct of business games and "The Factories of Processes" makes it possible to reconstruct the work of the individual office or the entire polyclinic. The possibility of standardization of medical processes, use of check-lists in the work and organization of each cabinet, introduction of the system " $5 S$ " and identification of medical losses with subsequent optimization of the initial reception is presented. In this work "The Process Factory" "The optimization of the appointment of a doctor-specialist" is presented, allowing to make a detailed analysis of the duration and structure of the reception, to perform the mapping of medical processes and to use visual management, considering the efficiency, Safety and quality of the doctor's work. The acquired skills in simulated conditions help to implement this methodology and effectively use the tools of lean technologies in practice.

Keywords: lean technologies in health care, "Process Factory", optimization, nutritionist, mapping, system " 5 ", medical losses, standardization, check-list.

\section{Introduction}

The organization of the activities of the nutrition service is regulated by the Order of the Ministry of Health of 15.11.2012. 920n "On approval of the Procedure for the provision of medical assistance to the population in the field of "nutrition" (registered in the Ministry of Justice of Russia on 17.04.2013, 28162) as well as local regulations of health care institutions providing primary health care to the population $[1 ; 2]$. Annex 1 of the above-mentioned Order "Rules of the Organization of the Activities of the Office of the Physician-Dietician" establishes the procedure for the organization of the activities of the Office of the Physician-Dietician established within the structure of the medical organi-

(C) St. Petersburg State University, 2020 
zation for the purpose of carrying out the consultative activities, diagnostic and curative assistance according to the profile of "dietetics". Annex 3 of the Order establishes the necessary equipment for the dietician's office: a phonendoscope, a tonometer with a set of children's cuffs, a medical balance, a rostometer, a centimeter tape, a caliper, a portable glucometer, a manual biochemical analyser, A bioimpedance machine and a computer. Organization of practical activities of doctors-nutritionists and nurses of health care institutions providing primary health care in the field of "nutrition" is traditionally conducted at the workplace. However, failure to observe the principles of frugal health care leads to loss and defects in the provision of medical care. In accordance with the Federal Law of the Russian Federation of 21.11.2011 no. 323 "On the Fundamentals of Health Protection of Citizens in the Russian Federation", as well as the Methodical Recommendations of the Ministry of Health of the Russian Federation, "Implementation of projects on improvement using methods of economical production in the medical organization providing primary health care" since 2016 in the institutions of primary health care is being implemented in priority project "New model of medical organization providing primary health care" $[3 ; 4]$. The main objective of the project is to improve the organization of primary health care for the population. The shift towards a patient-centred approach in primary health care is ensured not only by administrative decisions, but also by the creation of an integrated management concept based on the principles of a continuous flow of values creation, Address medical and other losses.

Among the existing losses in the work of a nutritionist, particular attention should be paid to patient waiting times for reception or manipulation, defects in the organization of patient routing, prolonged examinations, examinations and insufficient information support [5-7]. There has also been an irrational use of the working hours of the dietician and the nurse, which has led to increased waiting times, queues and, consequently, a negative attitude of patients towards the quality of care. According to the principles of the standardization of medical care, it is necessary to "mentor" and transfer clinical experience to young specialists, which is possible when creating adapted algorithms of manipulation and standard operating procedures of medical processes. The desire to improve the accessibility and quality of medical care determines the need to optimize the work of the service of a nutritionist at the initial appointment of a medical organization [8].

\section{Materials and methods of research}

Training Centre for Lean Technologies in Health Care of the St. Petersburg State Pediatric Medical University was established in 2018 with the aim of training medical workers in various specialties in the use of the tools of economical production in a simulated clinic and the subsequent introduction of the acquired tools skills in medical organizations [9]. Simulation of medical processes in a simulated clinic in real-time conditions has made it possible to identify problems of medical dietary consultation with subsequent optimization of work using economical technologies [10]. The conduct of "process factories" and business games imitating the appointment of a doctor-nutritionist, webinars, remote courses with subsequent analysis of the work done make it possible to organize the working space in the doctor's office optimally a specialist using tools of economical technologies, increase the time for examination of a patient, optimize the flow of documents, redistribute functional responsibilities between medical and nursing staff. 
On the basis of the Training Centre in 2018-2019 "process factories" and business games were held for primary health care specialists (including nutritionists, gastroenterologists, endocrinologists and nurses) with a view to mastering the instruments of economical technologies. The study included 168 health workers sent from clinics to optimize field work. "Process factories" were modeled according to the direction of training of the listeners: "dietetics", "nutritiology", "optimization of the appointment of the doctor-specialist". "The factories" consisted of several stages of sequential passing of the whole chain of the given medical process. Each phase was followed by debriefing, identifying problems and identifying optimization options. This repetition of similar processes has resulted in the loss of medical care [11].

Results: Conducting "Process Factories" and Business Games in the initial stages of the optimization system implementation, made it possible to define the initial level of knowledge of medical workers about tools of economical production, ways of optimization and standardization of medical activity. All trainees were tested on workplace optimization issues with the help of mapping, the " $5 S$ " system, Ishikawa and "Spaghetti" diagrams and other tools of thrifty technologies [5; 12; 13]. In 124 (73.8 per cent) trainees, the initial test result was less than 70 per cent, which determined the need for a detailed review of the theoretical material before starting practical work. In addition, in 67 (39.9\%) observations, participants received less than $50 \%$ of the correct answers. Thus, the necessity of creating additional materials for the listeners was determined, and for carrying out the first stage of "process factory" There is a low level of readiness among the medical staff to take advantage of the possibilities of introducing the tools of economical technologies into practical activities and, as a result, ways of optimizing within and outside the cabinet are illustrated.

In case of "Factories of processes", based on the modeling of the appointment by the doctor-nutritionist, it is initially noted that a significant part of the time spent by the patient in the office of the doctor-specialist has not brought "benefits" to any side of the process. When "Factories" was repeated by similar specialists it was possible to reduce the duration of patients' reception by 6 minutes (initially -22 minutes), due to the reduction of time for searching and processing of medical documentation, execution of repeated low-informative researches.

During the "Factory of Processes" the queue was monitored (waiting time, number of people, understanding of the location of the offices). It has been determined that the average waiting time for the simulation of a full-fledged appointment of specialist doctors was 45 minutes on average. The redistribution of responsibilities between doctors and nurses has resulted in a reduction in waiting times in the queue to 20 minutes and in compliance with estimated targets. In addition to the developed scenario of a dietician doctor's appointment, the following scenarios "Process Factories" have been developed and introduced in the Training Centre of Economical Technologies in Public Health Care: optimization of the work of the register and the map repository, optimization of the work of the procedural cabinet, Optimization of the admission of specialist doctors (district pediatrician, pediatric surgeon, endocrinologist, gastroenterologist); optimization of the dispensing of healthy children (specified ages). Optimizing the treatment of children with chronic somatic diseases, optimizing the treatment and preventive examinations of adults, and optimizing the treatment of adults with chronic non-communicable diseases. All scenarios were simulated in a simulated clinic based on the needs of the participants. All 
scenarios took into account the need to optimize the activities of a nutritionist or related physicians (endocrinologist, gastroenterologist) [14; 15].

Each "Factory of Processes" consisted of three rounds with inter-round discussions - debriefing with implementation of proposals for improvements taking place in 2 school days [11]. Initially, participants participated in the scenario based on their own knowledge of the organization of medical processes. The video recording made it possible to identify the most striking problems in the organization of work. After the debriefing of the first stage, the theoretical foundations of the formation of medical activity were taught on the basis of the instruments of economical production. Special attention was paid to algorithms of medical processes, patient routing (using "spaghetti" methods, mapping of second and third levels, "bottleneck analysis", "Takt time" and "Total Productive Maintenance".

In consolidating the information received, the second phase, with the help of trainers and tutors, demonstrated the changes that had been achieved through the implementation of the tools. For example, organizing the workplace, changing the location of furniture or equipment inside the room, implementing patient routing algorithms and medical records, and algorithms for recording doctors, Experts, preparation and execution of laboratory and instrumental research, as well as introduction of automated operating systems for electronic workflow of various modifications, They have made it possible to demonstrate the efficiency of the use of the tools of economical production and the prospects for their practical application. This was demonstrated by the achievement of targets for the number of patients admitted, the time taken to process medical records, the reduction in waiting times and the number of complaints from patients or their legal representatives in all simulations conducted. On the second day of the training seminars, during the third phase, suggestions for improvement were made by the participants on the basis of the acquired knowledge. It has been noted that participants have acquired theoretical knowledge on the use of various tools of economical technologies based on the needs and practical skills of their implementation, which was defined as a continuing commitment to the use of the instruments of frugal production in its activities.

During the "Process Factories" stages, using the visual management methodology using adapted graphical tables, losses have been identified and, during debriefing, ways of optimization have been proposed. Medical losses identified during the conduct of business games and "Process Factories" are generalized to the groups proposed by Taiichi Ono: "overproduction", “excess movements", “excess stocks", "excess processing”, "prolonged waiting", "marriage", "excess transportation” [16].

In the loss group "surplus stock" was found: the presence of office supplies, writing paper, unused forms, some of which are obsolete in volume exceeding the monthly norm. On the shelves are outpatient records of patients who have completed treatment. In the "marriage" group, losses have been identified: violation of algorithms and standards of medical care on individual nosologies related to "dietetics" profile, detected during internal control assessment of the quality of medical care; low-informative entries in primary medical documentation, errors in the entry of patient data into the information system, lack of control anthropometric research, violation by patients of the technique of preparation for instrumental diagnostic methods, Limited duration of laboratory results.

Losses related to oversupply in the dietician's office were excessive copying of medical documents, forms, including announcements for district doctors and doctors in related 
professions; duplicate reports Primary medical documentation forms, investment of financial resources in navigation, redevelopment of the health-care institution prior to the optimization and routing process. Excess processing is related to vague job descriptions for medical personnel, duplication of functions performed by a medical dietician, district pediatricians, specialist doctors, and between medical and nursing staff, the appointment of repeated or duplicative laboratory tests or of low-informative tests, excessive agreement in the assignment of research or therapy, the prescription of unwarranted or excessive therapy (polypragmasia). Long waiting times, lack of automatic information systems, delays of patients and medical staff, lack of specialized specialists (gastroenterologists, endocrinologists, pediatric surgeons, geneticists), inefficient use of working time, Long period of agreement for taking administrative decisions unites the loss group "long wait". The formation of the group "extra transportation" is connected with the lack of efficient navigation, which is connected with the long time to search necessary offices, the irrational arrangement of offices, equipment and furniture inside offices, Lack of algorithms and instructions for medical personnel. The redundant movements are due to the inconvenience of the interface of the automated information network, the irrational arrangement of offices and equipment inside, the transmission of reports, outpatient maps and other documents by hand, and the holding of face-to-face meetings.

Discussion. Recommendations have been developed and implemented for each group of losses identified in simulated conditions using tools of economical production. Common: development of standard operating procedures (office equipment, medical procedures), introduction of electronic workflow with electronic medical records, Introduction of a special programme to assess the nutritional status of a patient and a set of patient statistics that can be applied in any day-care facility [7; 17]. Common functions for such programs should be: the ability to automatically assess the nutritional status according to the anthropometric parameters of a specific patient, the presence and extent of metabolic disorders (protein-energy insufficiency, excess body mass), as well as the possibility of informational support of a doctor-specialist in the personification of nutritional or endocrinological therapy. Such a program in St. Petersburg State Pediatric Medical University is the developed in 2017-2018 "Program Complex of Evaluation and Correction of Nutritious Status of Pediatric Hospital Patient Hospitalized" (Certificate of registration of the program for RU Computer 2018662238, date of registration 03.10.2018) [18].

Introduction of the system of organization of the workplace according to the method "5S": "sorting", "keeping order", "keeping clean", "standardization", "perfection" It has also made it possible to optimize the processes of providing medical care and to reduce the time required to find the necessary tools or materials. The design and implementation of the " 5 S" Workplace Inspection Scorecard in the course of training has enabled a better understanding of this tool of economical production. The creation of leaflets for patients indicating preparations for instrumental and laboratory studies has made it possible to reduce the number of defects in the corresponding diagnostic manipulations. The use of "spaghetti" methods, mapping with formation of maps of flows of the second and third levels allowed to minimize overproduction. The use of colour markings in the organization of the workplace, warehouse, open registry and card repository (with priority in the formation of electronic document circulation) made it possible to find the desired object in a timely manner without additional time costs. Treatment of patients according to clinical recommendations, standards and protocols has allowed, On the one hand, to 
minimize the cost to the health-care institution and patients and their parents of purchasing medicines and carrying out low-informative laboratory and instrumental research; on the other hand, to improve the efficiency of treatment and the commitment of patients to therapy. The introduction of visual navigation based on time-series data has made it possible to minimize unnecessary movements of both patients and medical personnel and medical supplies. In the final test all participants demonstrated good results of mastering principles and tools of economical technologies.

\section{Conclusions}

1. The study of the tools of economical technologies in simulating a dietician in a simulated clinic allows to effectively master the skills of optimizing medical processes and to use the acquired knowledge in practice.

2. Universal tools of economical production providing elimination of any kind of medical losses have been identified: system “5S", standardization of operational procedures and informatization during organization of activity.

3. The conduct of "Process Factories" and business games under the conditions of a simulated clinic and the comprehensive introduction of tools of economical technologies allows to optimize the activity of the nutritionist doctor in the health care establishment and, As a result, improve the quality of health care for the population.

\section{References}

1. Vumek D. P., Dzhons D. T. Sustainable Production: How to Get Rid of Losses and Bring Prosperity to Your Company, per. s angl. $2^{\text {nd }}$ ed. Moscow, Al'pina Biznes Buk Publ., 2005. 473 p. (In Russian)

2. Artem'ev S. A., Il'in S. N. Conservation technologies will come to all. Successful experience of implementation. Zamestitel' glavnogo vracha, 2017, no. 6, pp. 14-23. (In Russian)

3. Kuprina I. K., Rumjanceva E.E., Smirnova N.V., Bahyshov R. D. O. Improving the efficiency of medical institutions through the use of economical technologies. Vestnik Akademii znanii, 2020, no. 4 (39), pp. 248-252. (In Russian)

4. Lisovskii O. V., Gostimskii A. V., Lisitsa I. A., Kocharyan S. M., Prudnikova M.D., Selikhanov B. A., Getsko N. V., Abubakarova M.R., Lisovskaia E. O., Gostimskii I. A. Development of tools of economical technologies in simulated conditions. Virtual'nye tehnologii v medicine, 2019, no. 2 (22), p. 59. (In Russian)

5. Artem'ev S. A., Il'in S. N., Romanova Ju. A. Conservation technologies in the doctor's office. 5 steps, how to organise the working space. Zamestitel' glavnogo vracha, 2017, no. 8, pp. 44-51. (In Russian)

6. Senenko A. Sh., Son I. M., Dzjuba N. A., Zaharchenko O. O., Terent'eva D. S., Shelgunov V. A. Sustainable Production Technologies in Reforming Medical Organizations Providing PHC. Analytical Review. Sotsial'nye aspekty zdorovia naseleniia, 2020, vol. 66, no. 4, p. 6. (In Russian)

7. Lastoveckij A.G., Titov I.G., Kitanina K. Ju. Evaluation of the principles of sustainable production in health-care institutions in the future and in the present. Vestnik novykh meditsinskikh tehnologii. Elektronnoe izdanie, 2018, no. 4, pp. 83-93. (In Russian)

8. Pyreva E. V., Noskova V.A., Pozdeeva T.V. Economical technologies in primary health care in rural outpatient clinics. Menedzher zdravookhraneniia, 2020, no. 6, pp. 22-27. (In Russian)

9. Lisovskii O.V., Gostimskii A. V., Prudnikova M.D., Lisitsa I. A., Kocharyan S. M., Krakovskaia K. A., Abubakarova M. R., Likhachevskaia I. V., Musaeva A. Sh. Introduction of economical technologies in training of district pediatrician. Virtual'nye tehnologii v meditsine, 2018, no. 2 (20), pp. 48-49. (In Russian)

10. Lisovskii O.V. Principles of efficient operation of polyclinic on the example of factory of processes in simulated conditions. Aktual'nye voprosy pervichnoi mediko-sanitarnoi pomoshchi, 2018, pp. 526-527. (In Russian)

11. Arzhencov V.F., Gajvoronskaja T. V., Veselova D. V., Vermennikova L. V., Chabanec E. A. Evaluation of the effectiveness of the method of "learning by action" at the "factory of processes" in order to apply 
the philosophy, principles and tools of economical production in medical organizations. Sovremennye problemy nauki i obrazovaniia, 2019, no. 2, p. 1. (In Russian)

12. Kurmangulov A.A., Reshetnikova Ju. S., Sheveleva O.E., Bazhuhina A.D. Requirements for the organization of the workplace of medical personnel in the implementation of the $5 \mathrm{~S}$ method of economical production. Vestnik Ivanovskoi meditsinskoi akademii, 2019, vol. 24, no. 1. pp. 42-46. (In Russian)

13. Kurmangulov A.A., Reshetnikova Ju. S., Bagirov R.N., Frolova O.I., Brynza N.S. Possibilities of the Ishikawa diagram as a tool of economical production in health care in the Russian Federation. Zabajkal'skii meditsinskii vestnik, 2018, no. 3, pp. 37-45. (In Russian)

14. Gostimskii A.V., Lisovskii O.V., Selihanov B.A. Simulation training of clinical residents of various specialties. ORGZDRAV: novosti, mneniia, obucheniia. Vestnik VShOUZ, 2018, no. 2 (12), pp. 56-57. (In Russian)

15. Zavyalova A.N., Gostimskii A.V., Lisovskii O.V., Chujnyshena S.A., Luzanova O.A. Role of algorithms for estimating the nutritional status of a hospitalized child in the practice of a pediatrician. Meditsina: teoriia i praktika, 2018, vol. 3, no. 1, p. 33. (In Russian)

16. Kulikov O. V., Sheppli E. V. Lean-transformation of the inpatient receiving department. Step one: from concept to searching for hidden losses of quality. Menedzhment kachestva v meditsine, 2019, no. 2, pp. 92-97. (In Russian)

17. Gostimskii A. V., Kuznetsova Ju. V., Lisovskii O. V. Organization of simulation training at SPBGPMU. Pediatr, 2015, vol. 6, no. 3, pp. 118-122. (In Russian)

18. Zavyalova A. N., Gostimskii A. V., Chujnyshena S. A., Lisovskii O. V., Luzanova O. A. Program complex of evaluation and correction of the nutritional status of a patient in a paediatric hospital. Svidetel'stvo o gosudarstvennoi registratsii programmy dlia JeVM № RU 2018662238, data registratsii 16.02.2018. (In Russian)

Authors' information:

Oleg V.Lisovskii - MD, PhD, Associate Professor; oleg.lisovsky@rambler.ru

Alexandr V. Gostimskii - MD, PhD, Dr. Sci. (Medicine), Professor; gostimsky@mail.ru

Ivan A. Lisitsa - MD, Assistant; ivan_lisitsa@mail.ru

Anna N.Zavyalova - MD, PhD, Associate Professor; anzajalova@mail.ru

Igor V.Karpatsky - MD, PhD, Associate Professor; ikar122@list.ru 